\title{
KARAKTER FINAL PUTUSAN MAHKAMAH KONSTITUSI DALAM MELAKSANAKAN KEWENANGAN SESUAI PASAL 24C AYAT ( 1) UNDANG-UNDANG DASAR NEGARA REPUBLIK
}

\author{
INDONESIA TAHUN 1945.
}

\author{
Oleh : \\ Zuhro Nuridahwati \\ Program Studi, Fakultas Hukum Universitas Mahendradatta \\ Jl. Ken Arok No. 12 , Peguyangan Denpasar Utara, Bali 80115. \\ (zuhro235@gmail.com)
}

\begin{abstract}
Abstrak. Mahkamah Konstitusi berada dalam ruang lingkup Kekuasaan Kehakiman dan menempati posisi strategis dalam struktur ketatanegaraan Indonesia. MK sebagai salah satu lembaga negara yang dilahirkan dari reformasi tahun 1998. MK sebagai lembaga peradilan punya tugas yang sangat penting dan strategis, dikatakan sebagai penafsir tunggal konstitusi negara Republik Indonesia. Pasal 24C ayat (1), UUD NRI 1945, Mahkamah Konstitusi berwenang mengadili pada tingkat pertama dan terakhir yang putusan bersifat final untuk menguji undang-undang terhadap Undang Undang Dasar, memutus sengketa kewenangan lembaga negara yang kewenangannya diberikan oleh Undang Undang Dasar, memutus pembubaran partai politik, dan memutus perselisihan tentang hasil pemilihan umum. Hasil kajian dan analisis, ketentuan UUD NRI 1945 dan UU Nomor 24 Tahun 2003, menemukan isu hukumyang menjadi problem hukumyang dihadapi Mahkamah Konstitusi,adalah terkait dengan kedudukannnya, kompetensi, dan bentuk putusan, yang sering membuat kepastian hukum menjadi tidak pasti atau absur, dan konflik norma, sangat menarik untuk dikaji sebagai tema sentral disertasi. Pengertian Kedudukan, menunjukkan posisi dan derajat Mahkamah Konstitusi diantara lembaga negara dan antara Mahkamah Agung dengan Mahkamah Konstitusi, sedangkan kompetensi menunjukkan batas kompetensi antara MK dan MA, yang memiliki kewenangan attributie, kewenangan yang pertama dan utama, dilahirkan dari format sistem pemerintahan dan pembagian kekuasaan negara. Kewenangan attributie sebagai sentral pertama dan utama untuk tanggungjawab dan sekaligus dasar melimpahkan kewenangan dalam bentuk delegatie.
\end{abstract}

Kata Kunci : Keweangana mahkamah konstitusi 
Abstract. The Constitutional Court is within the scope of the Judicial Power and occupies a strategic position in the Indonesian constitutional structure. MK as one of the state institutions that was born from the reformation in 1998. MK as a judicial institution has a very important and strategic task, said to be the sole interpreter of the Republic of Indonesia's state constitution. Article 24C paragraph (1), of the 1945 Constitution of the Republic of Indonesia, the Constitutional Court has the authority to adjudicate at the first and last level the final decision to review the law against the Constitution, to decide on disputes over the authority of state institutions whose authority is granted by the Constitution, to decide upon the dissolution of parties politics, and decide upon disputes about the results of general elections. The results of the study and analysis, the provisions of the 1945 Constitution of the Republic of Indonesia and Law Number 24 Year 2003, found legal issues that become legal problems faced by the Constitutional Court, are related to their position, competence, and form of decisions, which often makes legal certainty uncertain or absurd, and conflicts norm, it is very interesting to be studied as a central theme of the dissertation. Understanding the Position, indicating the position and degree of the Constitutional Court between state institutions and between the Supreme Court and the Constitutional Court, while competency shows the competency boundary between the Constitutional Court and the Supreme Court, which has attributie authority, first and foremost authority, born from the format of the government system and the distribution of state power. Attributie authority as the first and main center for responsibility and at the same time the basis of delegating authority in the form of delegatie.

\section{Keywords: Constitutional court authority}

\section{PENDAHULUAN}

\subsection{Latar Belakang}

Majelis Permusyawaratan

Rakyat (MPR) Periode Tahun 2014-

2019, membentuk Badan Pengkaji,

untuk menyiapkan rancangan

Perubahan Undang Undang Dasar
Negara Republik Indonesia Tahun

1945 (UUD NRI 1945) yang ke-5, 
telah menghasilkan 15 isu strategis, ${ }^{93}$

sebagai berikut:

(1). Penegasan Pancasila sebagai dasar dan ideologi Negara, (2). Penguatan sistem demokrasi Pancasila,(3). Penataan sistem hukum berdasarkan Pancasila,(4). Penguatan lembaga MPR,(5). Laporan kinerja lembaga negara pada sidang Tahunan MPR, (6). Menegaskan materi dan status hukum ketetapan MPR/MPRS, (7). Penguatan sistem Presidensial,(8). Reformasi sistem perencanaan pembangunan nasional dengan model GBHN,(9). Penataan sistem perekonomian nasional,(10). Penguatan wewenang DPD, (11). Mengkaji TAP MPR No.I/MPR/2003 Terutama Tentang Pencabutan Ketetapan MPR RI No.II/MPR/1978 tentang Pedoman Penghayatan dan Pengamalan Pancasila dan Penetapan Tentang Penegasan Pancasila sebagai dasar negara,(12). Penetapan UU tersendiri tentang MPR, DPR, dan DPD,(13). Penataan Kewenangan Komisi Yudisial,(14). Penataan kewenangan Mahkamah Agung,(15). Penataan kewenangan

93Bambang Sadono, 2016, Amandemen Jalan Tengah, Kompas, 1 September 2016, hlm. 6
Mahkamah Konstitusi.

Isu strategis yang dihasilkan

Badan Pengkaji MPR. MPR ingin menata kembali lembaga negara, oleh sebab itu sangat menarik untuk dikaji isu-isu strategis tersebut, yaitu isu 13,14 , dan 15 . Kalau, ketiga isu strategis tersebut dikaji, terlalu luas saya pilih salah satu isu strategis tersebut, yaitu Penataan kewenangan Mahkamah Konstitusi, dan khusus mengenai makna, hakikat, dan substansi putusan pada tingkat pertama dan terakhir yang putusan bersifat final, sesuai dengan Pasal 24C ayat (1) UUD NRI 1945. Kemudian, Badan Pengkaji MPR, mengelompokkan ke-15 isu strategis tersebut menjadi 5 topik pokok,${ }^{94}$ berikut:

(1). Revitalisasi dan Reaktualisasi Pancasila

94Ibid. 
sebagai dasar negara, ideologi bangsa dan negara, dan sumber hukum nasional,

(2). Penataan kewenangan MPR,

(3). Reformasi sistem perencanaan

pembangunan nasional model GBHN,

(4). Penataan kewenangan DPD,

(5). Penataan kewenangan kekuasaan kehakiman

Mahkamah Konstitusi

berada dalam ruang lingkup

Kekuasaan Kehakiman dan

menempati posisi strategis dalam

struktur ketatanegaraan Indonesia.

MK sebagai salah satu lembaga negara yang dilahirkan dari

reformasi tahun 1998. MK sebagai

lembaga peradilan punya tugas yang

sangat penting dan strategis,

dikatakan sebagai penafsir tunggal

konstitusi negara Republik

Indonesia. Seiring dengan

perjalanan waktu Mahkamah

Konstitusi banyak menghadapi persoalan dan problema dalam

menjalankan tugas dan fungsinya.

Karena, banyak putusan Mahkamah

Konstitusi tidak bisa dilaksanakan

oleh lembaga yang lain.

Perubahan paradigma sistem

kekuasan kehakiman

Indonesia,setelah amandemen ke-3

UUD 1945, adalah melahirkan

kekuasaan kehakiman bifurkasi

(bifurcation), dapat dilihat dari

ketentuan Pasal 24 UUD NRI 1945.

Pasal 24 ayat (1), Kekuasan kehakiman merupakan kekuasaan yang merdeka untuk menyelenggarakan peradilan guna menegakkan hukum dan keadilan.

Pasal 24 ayat (2), Kekuasaan kehakiman dilakukan oleh sebuah Mahkamah Agung dan badan peradilan yang berada di bawahnya dalam lingkungan peradilan umum, lingkungan peradilan agama, lingkungan peradilan meliter, lingkungan peradilan tata 
usaha negara dan oleh sebuah Mahkamah Konstitusi.

\section{Menurut Ibrahim R,}

berdasarkan ketentuan Pasal 24 ayat

(2) UUD NRI 1945, bahwa kekuasaan

kehakiman mengalamai perubahan

paradigma, adalah kekuasaan

kehakiman yang berada ditangan

Mahkamah Agung dan Mahkamah

Konstitusi, yang menjadikan negara

Indonesia menganut bifurkasi sistem

(bifurcation system), ${ }^{95}$ yaitu:

Kekuasan kehakiman
Indonesia disebut bifurcation,
karena,ordinary (pengadilan biasa) berpuncak pada Mahkamah Agung, sedangkan constitutional review (uji konstitusional), yang berwenang untuk melakukan pengujian terhadap undang-undang, kendati Mahkamah Agung berhak melalukan pengujian

\begin{tabular}{lrr}
\multicolumn{2}{c}{ 95Ibrahim $\mathrm{R}, 2003}$, & Sistem \\
Pengawasan Konstitusional & Antara \\
Kekuasaan Legislatif dan Eksekutif Dalam
\end{tabular}

terhadap undang-undang, pada saat kasus dan perkara sampai di tingkat Kasasi, di samping hak uji Mahkamah Agung terhadap peraturan perundang-udangan di bawah undang-undang.

Dalam rangka, memahami makna filosofis keberadaan dan kompetensi Mahkamah Konstitusi, perlu dikaji secara teoritik dan praksis, makna dan hakikat Pasal 24C UUD NRI 1945 dan kemudian dilaksanakan oleh UU No. 24 Tahun 2003 tentang Mahkamah Konstitusi juncto UU No. 8 Tahun 2011 tentang Perubahan Atas UU No. 24 Tahun 2003 tentang Mahkamah Konstitusi.

Pasal 24C ayat (1), UUD NRI 1945, Mahkamah Konstitusi berwenang mengadili pada tingkat pertama dan terakhir yang putusan bersifat final untuk menguji undangundang terhadap Undang

Pembaruan UUD 1945, Pascasarjana Universitas Padjadjaran, Bandung, h. 301302 


Undang Dasar, memutus
sengketa 4 kewenangan
lembaga negara yang
kewenangannya diberikan
oleh Undang Undang Dasar,
memutus pembubaran partai
politik, dan memutus
perselisihan tentang hasil
pemilihan umum.

${ }^{96}$ Pir A. Partanto , M. Dahlan Al Barry, Kamus Ilmiah Populer, Penerbit Askola Surabaya, h 187
Dalam melaksanakan kewenangan Mahkamah Konstitusi mengadili tingkat pertama dan terakhir yang putusannya bersifat final. Untuk itu perlu saya uraikan arti final dalam arti secara etimologi. Final artinya yang akhir, akhir (tahap) penentuan juara, tujuan akhir (yang menentukan). ${ }^{96}$ Arti final dalam kamus besar bahasa Indonesia, frase final dan mengikat dalam kalimat Putusan Mahkamah Konstitusi bersifat final dan mengikat memiliki makna tersendiri. Frase final berarti tahapan (babak) terakhir dari rangkaian pemeriksaan (pekerjaan, pertandingan) sedangkan frase mengikat berarti menguatkan (mencengkam). Bertolak dari arti harfiah ini, maka frase final dan frase mengikat memiliki arti yang saling terkait, artinya akhir dari suatu proses pemeriksaan, telah memiliki kekuatan mengeratkan atau menyatukan semua kehendak dan tidak dapat dibantah lagi. ${ }^{97}$

Makna harfiah di atas, bisa dikaitkan dengan sifat final dan mengikat dari putusan Mahkamah Konstitusi artinya telah tertutup bagi segala kemungkinan untuk

$$
\begin{aligned}
& { }^{97} \text { Jurnal Mahkamah Konstitusi, h } \\
& 81-82
\end{aligned}
$$


menempuh upaya hukum setelahnya.

Tatkala putusan tersebut diucapkan dalam sidang pleno maka ketika itu lahir kekuatan mengikat secara hukum (Binding).

Akhir dari suatu proses pemeriksaan telah memiliki kekuatan mengeratkan atau menyatukan semua kehendak dan tidak dapat dibantah lagi. Yang dimaksud putusan Mahkamah Konstitusi final yakni putusan Mahkamah Konstitusi langsung memperoleh kekuatan hukum tetap sejak diucapkan dan tidak ada upaya hukum yang dapat di tempuh, sifat final dalam putusan Mahkamah Konstitusi ini mencakup pula kekuatan hukum mengikat (final and binding). ${ }^{98}$ Peradilan yang disebabkan

98 Mukti Arto, Praktek Perkara Perdata pada Pengadilan Agama, Yogyakarta, pustaka Pelajar, 1996. h 168 adanya dua pihak yang berlawanan dalam berperkara yaitu Penggugat atau Tergugat. Artinya putusan adalah hasil memutuskan berdasarkan pengadilan, dia dibebaskan. ${ }^{99}$
99 Penjelasan pasal 10 ayat (1) UU No. 8 tahun 2011 tentang Perubahan atas UU No. 24 tahun 2003 tentang MK (UU 8/2011). 
Mukti Arto, putusan ialah pernyataan hukum yang dituangkan dalam bentuk tertulis dan diucapkan oleh hakim dalam sidang terbuka untuk umum, sebagai hasil dari pemeriksaan perkara gugatan (kontentius). Putusan dalam bahasa (Belanda) disebut Vonis atau alqadlau (arab) adalah produk. ${ }^{100}$ Putusan adalah pernyataan hakim yang dituangkan dalam bentuk tertulis dan diucapkan oleh hakim dalam sidang terbuka untuk umum sebagai hasil dari pemeriksaan perkara perdata.

Ralp C. Davis, keputusan adalah suatu hasil pemecahan masalah yang dihadapinya dengan tegas. Suatu keputusan adalah suatu jawaban yang pasti terhadap suatu pertanyaan keputusan harus menjawab sebuah pertanyaan tentang apa yang dibicarakan dalam hubungannya dengan suatu perencanaannya. Keputusan bisa pula berupa suatu tindakan terhadap pelaksanaan yang sangat menyimpang dari rencana semula. 
Mary Follet, keputusan adalah suatu hukum atau sebagai hukum situasi jika suatu fakta dari situasi itu bisa diperolehnya dan semua yang terlibat, baik pengawas ataupun pelaksana mau mentaati hukumnya atau ketentuannya maka tidak sama dengan mentaati suatu perintah, wewenang tinggal dijalankan, tetapi itu adalah wewenang dari hukum situasi.

\section{Prajudi Atmosudirjo,}

keputusan adalah suatu pengakhiran dari proses pemikiran tentang suatu masalah atau problema untuk menjawab suatu pertanyaan apa yang harus diperbuat guna untuk mengatasi masalah tersebut, dengan menjatuhkan sebuah pilihan pada suatu alternatif. Jadi dapat disimpulkan definisi dari keputusan adalah hasil dari pemikiran guna untuk memecahkan masalah yang dihadapi dalam situasi tertentu dalam menjawab segala permasalahan.

Pasal 24C ayat (1) UUD NRI

1945, dapat dielaborasi secara teoritik dan praksis, sebagai berikut:

1. Bentuk Putusan Mahkamah Konstitusi, adalah berwenang mengadili pada tingkat pertama dan terakhir yang putusan bersifat final, artinya putusan Mahkamah

Konstitusi langsung berlaku pada saat diucapkan dan tidak ada upaya hukum lagi.

2. Kewenangan Menguji Undang Undang, adalah menguji undang-undang terhadap Undang Undang Dasar dengan bentuk putusan bersifat final, dapat dibenarkan oleh doktrin kekuasaan kehakiman, karena, belum ada sengketa, hanya baru ada kepentingannya yang merasa dirugikan.

3. Kewenangan Sengketa, dalam doktrin kekuasaan kehakiman bahwa mengadili sengketa, tidak boleh difinal, kalau para pihak tidak puas, harus ada upaya hukum berikutnya. 
Tetapi, Mahkamah Konstitusi

diberikan kewenangan

mengadili sengketa dan

bentuk putusan bersifat final,

ketentuan Pasal 24C ayat (1)

UUD NRI 1945, bertentangan

dengan doktrin kekuasaan

kehakiman. ${ }^{101}$

Ketentuan Pasal 24C ayat (2)

kalau dihubungkan dengan Pasal 7B

UUD NRI 1945, menimbulkan

kontradiktif dari kedua pasal teraebut:

Pasal 24C ayat (2), Mahkamah Konstitusi wajib memberikan putusan atas pendapat Dewan Perwakilan Rakyat mengenai dugaan pelanggaran oleh Presiden dan/atau Wakil Presiden menurut Undang Undang Dasar.

Pasal 7B ayat (1), Usul pemberhentian Presiden dan/atau Wakil Presiden dapat diajukan oleh Dewan Perwakilan Rakyat kepada Majelis Permusyawaratan Rakyat hanya dengan terlebih dahulu mengajukan permintaan kepada Mahkamah Konstitusi untuk memeriksa, mengadili, dan memutus pendapat Dewan Perwakilan Rakyat bahwa Presiden dan/atau Wakil Presiden telah melakukan pelanggaran hukum berupa pengkhianatan terhadap negara, korupsi, penyuapan, tindak pidana berat lainnya, atau perbuatan tercela; dan/atau pendapat bahwa Presiden dan/atau Wakil Presiden tidak lagi memenuhi syarat sebagai Presiden dan/atau wakil Presiden.

Pasal 24C ayat (2) dan Pasal 7B ayat (1) UUD NRI 1945, menyebutkan bahwa Mahkamah Konstitusi merupakan lembaga negara, menempati posisi istimewa pada struktur

berikutnya, supaya para pihak yang tidak puas diberikan kesempatan mengajukan keberatan, sesuai dengan Dharma Hukum adalah Kepastian dan Keadilan. 
ketatanegaraan Indonesia, disatu

pihak Mahkamah Konstitusi bisa membuat kepastian hukum menjadi tidak pasti atau konflik. Hak uji undang- undang yang dilakukan para pihak, diberikan setelah undangundang diberlakukan.

UU No. 24 Tahun 2003 dan UU

No. 8 Tahun 2011, adalah UU tentang Mahkamah Konstitusi dalam rangka melaksanakan Pasal 24C ayat (1) dan ayat (2) UUD NRI 1945.Pasal 1 ayat (3) UU No. 24 Tahun 2003, mempertegas kembali kewenangan Mahkamah Konstitusi, seperti disebutkan Pasal 24C dan Pasal 7B UUD NRI 1945, Pasal 2 menyebutkan Mahkamah Konstitusi, salah satu lembaga negara.

Pasal 10 UU No. 24 Tahun 2003 tentang Mahkamah Konstitusi

$\begin{array}{ll}\text { Ayat (1), } & \text { Mahkamah } \\ \text { Konstitusi } & \text { berwenang }\end{array}$

mengadili pada tingkat pertama dan terakhir yang putusannya bersifat final untuk:

a. Menguji undang-undang terhadap Undang Undang Dasar Negara Republik Indonesia Tahun 1945

b. Memutus sengketa kewenangan lembaga negara yang kewenangannya diberikan oleh Undang Undang Dasar Negara Republik Indonesia Tahun 1945

c. Memutus pembubaran partai politik, dan

d. Memutus perselisihan tentang hasil pemilihan umum.

Ayat (2), Mahkamah Konstitusi wajib memberikan putusan atas pendapat DPR bahwa Presiden dan/atau Wakil Presiden diduga telah melakukan pelanggaran hukum berupa penghianatan terhadap negara, korupsi, penyuapan, tindak pidana berat lainnya, atau perbuatan tercela, dan/atau tidak lagi memenuhi syarat sebagai Presiden dan/atau Wakil Presiden sebagaimana dimaksud dalam Undang Undang Dasar Negara Republik Indonesia Tahun 1945 
Presiden, sebagai dasar untuk Ayat (3), Ketentuan sebagaimana dimaksud pada ayat (2), berupa:

a. Pengkhianatan terhadap negara adalah tindak pidana terhadap keamanan negara sebagaimana diatur dalam undang-undang.

b. Korupsi dan penyuapan adalah tindak pidana korupsi atau penyuapan sebagaimana diatur dalam undang-undang.

c. Tindak pidana berat lainnya adalah tindak pidana yang diancam dengan pidana penjara 5 (lima) tahun atau lebih.

d. Perbuatan tercela adalah perbuatan yang dapat merendahkan martabat Presiden dan/atau Wakil Presiden

e. Tidak lagi memenuhi syarat sebagai Presiden dan/atau Wakil Presiden adalah syarat sebagaimana ditentukan dalam Pasal 6 Undang Undang Dasar Negara Republik Indonesia Tahun 1945

Pasal 10 UU No. 23 Tahun 2003, memperluas pengertian tindak pidana atau kejahatan yang dilakukan oleh Presiden dan/atau Wakil meminta pertanggung jawaban Presiden dan/atau Wakil Presiden, artinya pembentuk undang-undang (DPR dan Presiden) memperluas pengertian apa yang diatur dalam Pasal 7A dan 7B UUD NRI 1945. Seharusnya, UU membentuk norma hukum dalam rangka melaksanakan ketentuan UUD NRI 1945, untuk dilaksanakan dan taat asas, seperti, Pasal 4 ayat (3) UU No. 24 Tahun 2003, menyebutkan masa jabatan Ketua dan Wakil Ketua Mahkamah Konstitusi, adalah 3 (tiga) tahun, artinya ada Ketua dan Wakil Ketua Mahkamah Konstitusi, sudah berakhir masa jabatannya, tetapi masih menjabat sebagai Ketua dan Wakil Ketua MK, kalaupun telah diubah oleh Pasal 4 ayat (3) UU No. 8 Tahun 2011, masa jabatan Ketua dan Wakil Ketua Mahkamah Konstitusi, 
adalah 2,6 (dua tahun enam bulan).

Dalam sistem ketatanegaraan dan pemerintahan, masa jabatan lembaga negara yang mendapat kewenangan attributie, adalah sesuai dengan periode pemilihan dan sekaligus melekat masa jabatan, misalnya lima tahun atau empat tahun. Masa jabatan Ketua dan Wakil Ketua Mahkamah Konstitusi, adalah lima tahun.

\section{Hukum Acara Mahkamah}

Konstitusi, diatur dalam Bab V UU Nomor 24 Tahun 2003, Pasal 28 ayat (1):
Pertanyaan, dari Pasal 28 ayat (1) tersebut, adalah mengapa Mahkamah Konstitusi memeriksa, mengadili, dan memutus dalam sidang pleno Mahkamah Konstitusi dalam keadaan luar biasa, dengan 7 (tujuh) orang hakim konstitusi yang dipimpin oleh Ketua Mahkamah Konstitusi, sedangkan dalam keadaan biasa dengan 9 hakim konstitusi. Kalau disidangkan dengan 7 hakim, lalu keputusannya secara teoritik bisa dengan 4 hakim. Empat 4 hakim, tidak mencerminkan dari tiga unsur asal muasal dari hakim konstitusi, yaitu tiga dipilih DPR, tiga dipilih Pemerintah, dan tiga dipilih Mahkamah Agung.

Pasal 45 ayat (7) UU No. 24 Tahun 2003:

Dalam hal musyawarah sidang pleno setelah diusahakan dengan sungguh-sungguh tidak dapat dicapai mufakat bulat, 
putusan diambil dengan suara terbanyak.

Kalau keputusan diambil dengan suara terbanyak atau voting, secara teoritik, berarti keputusan bisa diambil dengan 5 hakim konstitusi, kalau itu yang terjadi, tidak mencerminkan dari tiga unsur asal muasal hakim konstitusi (pilihan DPR, Presiden, dan MA), untuk mencerminkan ketiga unsur tersebut, seharusnya voting disetujui oleh minimal 7 (tujuh) hakim dari 9 (sembilan)hakim konstitusi. Kalau sidang pleno dilakukan oleh 7 hakim, secara teoritik, putusan dilakukan oleh 4 (empat) hakim, sangat tidak mencerminkan tiga unsur asal muasal hakim konstitusi. Persoalan semacam ini membuat kepastian hukum

102Ibrahim R, 2006, Pernak Pernik Yuridis Dalam Nalar Hukum, UPT Penerbit Unud, Denpasar, h. 1. menjadi tidak pasti atau absur, seharusnya praktik peradilan untuk memantapkan sistem hukum dan kepastian hukum, seiring dengan dalil, ${ }^{102}$ bahwa:

Teori dan praktik merupakan dua hal yang berpasangan, kalaupun tidak jarang keduanya bertentangan, tetapi, teori tanpa praktik, tidaklah lengkap, dan praktik tanpa teori tidak akan pernah mapan.

Pasal 50 UU Nomor 24 Tahun 2003:

Undang-undang yang dapat dimohon untuk diuji adalah undang-undang yang diundangkan setelah perubahan Undang Undang Dasar Negara Republik Indonesia Tahun 1945.

Dalam kenyataan, pengujian undang-undang yang dilakukan, 
misalnya, ketentuan Kitab UndangUndang Hukum Pidana (KUHP) yang berkaitan dengan tindak pidana korupsi, yaitu UU Nomor 31 Tahun 1999 tentang Pemberantasan Tindak Pidana Korupsi, UU Nomor 20 Tahun 2001 tentang Perubahan Atas UU Nomor 31 Tahun 1999 tentang Pemberantasan Tindak Pidana Korupsi. UU Tindak Pidana Korupsi, hukum materiilnya banyak diambil dalam KUHP.

Hasil kajian dan analisis, ketentuan UUD NRI 1945 dan UU Nomor 24 Tahun 2003, menemukan isu hukumyang menjadi problem hukumyang dihadapi Mahkamah Konstitusi,adalah terkait dengan kedudukannnya, kompetensi, dan bentuk putusan, yang sering membuat kepastian hukum menjadi tidak pasti atau absur, dan konflik norma, sangat menarik untuk dikaji sebagai tema sentral disertasi. Pengertian Kedudukan, menunjukkan posisi dan derajat Mahkamah Konstitusi diantara lembaga negara dan antara Mahkamah Agung dengan Mahkamah Konstitusi, sedangkan kompetensi menunjukkan batas kompetensi antara MK dan MA, yang memiliki kewenangan attributie, kewenangan yang pertama dan utama, dilahirkan dari format sistem pemerintahan dan pembagian kekuasaan negara. Kewenangan attributie sebagai sentral pertama dan utama untuk tanggungjawab dan sekaligus dasar melimpahkan kewenangan dalam bentuk delegatie. 